\title{
Ulnar Shaft
}

National Cancer Institute

\section{Source}

National Cancer Institute. Ulnar Shaft. NCI Thesaurus. Code C120676.

The prismatic, elong ated bony body of an ulna which curves from behind forwards, and compresses of the anterior, posterior and external surfaces separated by the anterior, posterior and interosseous borders. The distal portion of the shaft is rounded, smooth and bents outward. 